\title{
Evaluation of vegetative performance of maize with plowing management at Buner
}

\author{
Abid Khan ${ }^{1 *}$, Yousaf Jamal ${ }^{2}$, Faqir Gul ${ }^{1}$, Hidayat Ullah², Jawad Ali $^{2}$, \\ Ijaz Naeem ${ }^{3}$ and Mushtaq Ahmad Khan ${ }^{2}$ \\ 1. Agricultural Research Station, Buner, Khyber Pakhtunkhwa-Pakistan \\ 2. Department of Agriculture, The University of Swabi, Anbar-Pakistan \\ 3. Institute of Biotechnology and Genetic Engineering, The University of Agriculture Peshawar-Pakistan \\ *Corresponding author's email: akbuneri@gmail.com
}

Citation

Abid Khan, Yousaf Jamal, Faqir Gul, Hidayat Ullah, Jawad Ali, Ijaz Naeem and Mushtaq Ahmad Khan. Evaluation of vegetative performance of maize with plowing management at Buner. Pure and Applied Biology. Vol. 6, Issue 1, pp125-139. http://dx.doi.org/10.19045/bspab.2017.60005

\begin{tabular}{llll}
\hline \hline Received: 05/10/2016 & Revised: 31/12/2016 & Accepted: 06/01/2017 & Online First: 11/01/2017 \\
\hline
\end{tabular}

Abstract

An experiment was conducted at Agricultural Research Station Buner in summer 2014 to study the effect of plowing time i.e. in dark (at night) and in sunlight (at day) and sowing time i.e. immediate after plowing and 12 hours later, on various maize (Zea mays L.) hybrids. For this purpose, two fields were selected, one for daytime plowing and other for night time plowing. Night plowing was done at 10.00 p.m. while daytime plowing at 8.00 a.m. Furthermore; half of the plowed field was sown immediately after plowing and the rest, 12 hours later in both plowing treatments. Three hybrids of maize i.e. Monsanto-2021, Rafhan-3313 and Rafhan-3304 were planted in each field under randomized complete block design with four replications. All standard agronomic practices were adopted during the experiment for all treatments. All the observed parameters were significantly affected by plowing time, while sowing time had no impact. Generally, a significant interaction among plowing and sowing time was observed for the recorded parameters. Early emergence (7 days) was observed for the field plowed at night. Plowing the field at usual daytime delayed emergence (9 days). Delayed tasseling (52.9 days), delayed silking (58.6 days), larger leaf area $\left(850 \mathrm{~cm}^{2}\right)$, delayed maturity (114 days), taller plants $(271 \mathrm{~cm})$, greater stover yield $\left(12328 \mathrm{~kg} \mathrm{ha}^{-1}\right)$ and accelerated crop growth rate $\left(24.98 \mathrm{gm}^{-2}\right.$.day $\left.{ }^{-1}\right)$ were recorded for the field plowed at night. There were also significant differences among various hybrids, where Monsanto-2021 delivered better results. Plowing the field at night proved superior in term of crop growth rate as compared to the field plowed at usual daytime. Night plowing is recommended to increase vegetative performance of maize. Sowing can be done immediately after night plowing or on the subsequent day of plowing. Hybrids particularly, Monsanto-2021 is recommended for better performance.

Keywords: Maize; Night plowing; Monsanto-2021; Rafhan-3313 and Rafhan-3304

\section{Introduction}

Maize (Zea mays L.) belongs to family Poaceae. It is one of the leading cereal crops grown in all districts of Khyber Pakhtunkhwa. Mansehra and Buner valley are equally famous for maize cultivation. It 
might be due to the regional farming system, climatic conditions and its consumptive demand for grains [1].

The existing maize yield is quite low in the whole province. The major hurdle of this low yield is high weeds infestation. Weeds compete with maize for space, light, nutrients as well as water. High rainfall further restricts its eradication at proper stage of the crop growth. Dormancy is a state of inhibiting germination of a viable seed even if climatic conditions are favorable. It could be due to seed coat characteristics, embryo characteristics and presence of inhibitors or unavailability of light. Most of weed seeds belong to family Poaceae and by exposing its seeds to light could break the dormancy. Plowing land at day time in hot summer not only breaks the dormancy of weed seeds but also expedite the process of weed germination [2]. The already existed weed seeds are relatively turgid and start germination when exposed to light during the plowing. In comparison to that of main crop, the early weed establishment is mostly common in all fields. This enables weeds to dominate on the main crops in early developmental phase.

Soil preparation in the absence of light (at night) has not only reduced weeds emergence rate but also allow the main crops to germinate relatively early by providing sufficient moisture to the main crop and particularly to the maize which has larger seeds and are planted in extreme hot months of the summer. Plowing in night also has an advantage to conserve unusual Plowing Time Sowing time

$\begin{array}{ccl}\text { Night } & \text { Night } & \text { Immediately after plowing at } 10.00 \text { p.m. } \\ \text { (10.00 p.m.) } & \text { Day } & 12 \text { hours later, } 10.00 \text { a.m. on subsequent day of plowing } \\ \text { Day } & \text { Day } & \text { Immediately after plowing at } 8.00 \text { a.m. } \\ (8.00 \text { a.m.) } & \text { Night } & 12 \text { hours later, } 8.00 \text { p.m. on subsequent night of plowing }\end{array}$

Three hybrids namely Monsanto-2021 (H1), Rafhan-3313 (H2) and Rafhan-3304 (H3)

were planted in each field under randomized complete block design with four moisture losses from the field, which enables the maize to complete germination process faster with minimum duration than plowing in daytime. Maize seeds are relatively larger and needs sufficient moisture to complete germination. Summer in Khyber Pakhtunkhwa is relatively hot and creates considerable loss of soil moisture if fields are plowed at normal daytime. Field preparation in night might ensure sufficient moisture to the crop to complete the process of germination. This result optimum seedling emergence and ensure optimum plant stand and hence reflected greater production [3].

To know the effect of plowing management on seedling emergence, vegetative performance and plant growth rate along with plant stand at harvest were the main objectives of the study.

\section{Materials and methods}

The experiment entitled "Evaluation of Vegetative Performance of Maize with Plowing Management at Buner" was conducted at Buner in summer (Kharif season) 2014. The experiment consisted of two plowing time i.e. in dark (at night) and in sunlight (at day). Furthermore; half of the plowed field was sown immediately after plowing and the rest, 12 hours later in both plowing treatments. For this purpose, two fields were selected, one for day time plowing and other for night time plowing. Night plowing was done at 10.00 p.m. while day time plowing at 8.00 a.m. The plowing and sowing time was adjusted according to the following schedule. 
replications. A basal dose of $\mathrm{N}$ : P: $\mathrm{K}$ at the rate of 120:90:60 $\mathrm{kg} \mathrm{ha}^{-1}$ was evenly distributed at sowing time in the whole field. Nitrogen was applied in two equally split doses, half at sowing and the rest, after 30 days of sowing. The sources used for the nutrients were Urea, DAP and SOP. Weeding was done once after the canopy closure stage of the crop growth. A net plot size of $5 \mathrm{~m} \mathrm{x} 3.6 \mathrm{~m}$ was used which accommodated 6 rows of $60 \mathrm{~cm}$ apart.

A seed rate of $25 \mathrm{~kg} \mathrm{ha}^{-1}$ was used. Seeds were planted manually in furrows and covered thereafter immediately. Irrigation was done as per crop water demand. All standard agronomic practices were adopted during the experiment for all treatments.

The following observations were recorded during the crop growth stage.

\section{Days to emergence}

Days to emergence were recorded by counting the days taken by each treatment from the date of sowing till the completion of emergence.

\section{Emergence $\mathbf{~ m}^{-2}$}

Data regarding emergence $\mathrm{m}^{-2}\left(\mathrm{Em}^{-2}\right)$ were recorded about 16 days after sowing the crop. The numbers of plants were counted at three different places in each experimental unit with the help of $1 \mathrm{~m}$ long rod. Their mean was worked out and number of plants $\mathrm{m}^{-2}$ was calculated by using the following formula.

$\mathrm{Em}^{-2}=\frac{\text { no of plants counted }}{\mathrm{R}-\mathrm{R} \text { distance } \times \text { row length } \times \text { No. of rows }} \times 1 \mathrm{~m}^{2}$

\section{Days to $50 \%$ tasseling}

Data on days to $50 \%$ tasseling was recorded when more than $50 \%$ plants developed tassels in each treatment. Days were counted from sowing till the completion of $50 \%$ tassels.

\section{Days to 50\% silking}

Data on days to $50 \%$ silking was recorded when more than $50 \%$ plants developed silks in each experimental unit. Days were counted from sowing till the completion of $50 \%$ silks.

\section{Leaf area of the cob bearing node near maturity $\left(\mathrm{cm}^{2}\right)$}

Three plants were randomly selected in each treatment and harvested. Their cob's bearing leaves were detached. The length of each leaf as well as width at six different points was measured. The mean of each leaf's width was calculated and leaf area was determined as:

Leaf area $\quad=\quad$ length $\times$ mean width

\section{Plant height $(\mathbf{c m})$}

Height of three plants in each treatment was measured at maturity from soil surface to the tip of plant by using a measuring tape and the average plant height was calculated.

\section{Days to maturity}

Data on days to maturity was recorded from the date of sowing till the physiological maturity, when harvest was done.

\section{Stover yield ( $\left.\mathrm{kg} \mathrm{ha}^{-1}\right)$}

Stover yield (St yield) was recorded from the two central rows harvested for grain yield. The stovers were dried in the sun. Their sundry weight was recorded and converted to stover yield $\mathrm{kg} \mathrm{ha}^{-1}$ by using the following formula.

St yield $=\frac{\text { stover yield in } 2 \text { central rows }}{\mathrm{R}-\mathrm{R} \text { distance } \times \text { row length } \times \text { No. of rows }} \times 10000 \mathrm{~m}^{2}$

\section{Crop growth rate $\left(\mathrm{gm}^{-2} \cdot \mathrm{day}^{-1}\right)$}

A known area of $0.75 \mathrm{~m} \times 0.60 \mathrm{~m}$ in each treatment was harvested at 15 days' interval from emergence. The harvested samples were dried at $60^{\circ} \mathrm{C}$ for 40 hours. The dry weight was recorded and the means of all intervals was calculated. Crop growth rate was determined according to the formula as described by [4].

$\mathrm{CGR}=\frac{1}{\mathrm{GA}} \times \frac{(\mathrm{W} 2-\mathrm{W} 1)}{(\mathrm{T} 2-\mathrm{T} 1)}$

Where

$\mathrm{G}_{\mathrm{A}}=$ ground area

$\mathrm{T}=$ time 
$\mathrm{W}_{1}=$ dry weight of sample at first interval (15 DAE)

$\mathrm{W}_{2}=$ dry weight of sample at second interval (30 DAE)

The final samples were harvested after 105 days of emergence. The data collected on various parameters were analyzed statistically according to the appropriate methods. F-test was applied to detect the significant effects of treatments and LSD was used for means comparison. ANOVA was further split to understand and compare the means in details, for which contrasts were done.

\section{Statistical procedure}

The collected data for different parameters was subjected to analysis of variance (ANOVA) technology to find the difference, between different treatments. In case where the difference was significant the mean was further assist for differentiation through least significant difference (LSD) test. Statistical software, Statistix 8.1, was applied for computing both ANOVA and LSD [5].

\section{Results}

\section{Days to emergence}

Data regarding days to emergence of various maize hybrids as affected by plowing and sowing time is presented in Table 1. Statistical analysis of the data showed that plowing and sowing time (PS) had significantly affected days to emergence. There was no significant difference among the hybrids $(\mathrm{H})$ and their interaction with plowing and sowing time ( $\mathrm{PSxH})$ for days to emergence. The delayed (9 days) emergence was observed when the field was plowed at usual daytime and sown immediately, followed by the same field sown 12 hours later which took 8 days to emerge plants. The quickest emergence (6 days) were recorded when the field was plowed at night and sown immediately.

The manipulation of ANOVA indicated that the significant response of emergence was due to plowing time while sowing time had no effect. Furthermore, there was significant interaction between plowing and sowing time. The planned means comparison among plowing time showed that night plowing generally accelerated emergence ( 7 days) compared to daytime plowing (9 days).

Statistical analysis of the data showed that plowing time had significantly affected days to emergence while sowing time had no effect. The delayed emergence was observed when the field was plowed at usual daytime. The quickest emergence was recorded when the field was plowed at night. A significant interaction was observed between plowing and sowing time for days to emergence. Night plowing and immediate sowing speeded up the emergence. The early emergence might be due to the availability of sufficient moisture to the crop and in particularly to the maize which has larger seeds and are planted in extreme hot months of the summer i.e. June and July. Plowing in night also has an advantage to conserve unusual moisture losses from the field which enables particularly the maize to complete germination process faster with minimum duration than plowing in daytime. Our results indicate that sowing at dark accelerated the emergence which could be due to the effect of temperature. It seems that comparatively low temperature of night at sowing followed by a spell of 12 hours cool situation probably responsible for the initial boost of germination. [6] reported that optimum temperature for germination is 20 $25^{\circ} \mathrm{C}$. 
Table 1. Effect of plowing and sowing time on days to emergence of various maize hybrids

\begin{tabular}{|c|c|c|c|c|c|}
\hline \multirow{2}{*}{$\begin{array}{c}\text { Plowing } \\
\text { time }\end{array}$} & \multirow{2}{*}{$\begin{array}{c}\text { Sowing } \\
\text { Time }\end{array}$} & \multicolumn{3}{|c|}{ Hybrids } & \multirow{2}{*}{ Mear } \\
\hline & & H1 & $\mathrm{H} 2$ & $\mathrm{H} 3$ & \\
\hline \multirow{2}{*}{ Night } & Immediate & 6 & 6 & 7 & $6 \mathrm{~d}$ \\
\hline & $12 \mathrm{hrs}$ later & 8 & 7 & 8 & $7 \mathrm{c}$ \\
\hline \multirow{3}{*}{ Day } & Immediate & 9 & 9 & 9 & $9 \mathrm{a}$ \\
\hline & $12 \mathrm{hrs}$ later & 8 & 8 & 9 & $8 \mathrm{~b}$ \\
\hline & Mean & 8 & 7 & 8 & \\
\hline
\end{tabular}

LSD (0.05) for time $=0.59$, LSD $(0.05)$ for hybrids $=\mathrm{NS}, \mathrm{LSD}(0.05)$ for interaction $=\mathrm{NS}$

H1 = Monsanto-2021, H2 = Rafhan-3313, H3 = Rafhan-3304

Mean values of various categories followed by different letters are statistically different at $5 \%$ level of probability.

Planned means comparison with statistical significance

\begin{tabular}{|l|c|c|c|c|}
\hline \multicolumn{1}{|c|}{ Contrasts } & \multicolumn{3}{c|}{ Days to emergence } & Significance \\
\hline Night vs. day (plowing) & 7 & vs. & 9 & $* *$ \\
\hline Immediate vs. late (sowing) & 8 & vs. & 8 & NS \\
\hline Interaction (P x S) & - & - & - & $* *$ \\
\hline
\end{tabular}

NS = Non-significant

$* *$ = Significant at $1 \%$ level of probability

\section{Emergence per unit area $\left(\mathbf{m}^{-2}\right)$}

Data concerning emergence per unit area of various maize hybrids as affected by plowing and sowing time is presented in Table 2. Analysis of variance of the data showed that plowing and sowing time (PS) and their interaction with hybrids $(\mathrm{PSxH})$ had significantly affected emergence per unit area. There was no significant difference for per unit emergence among different hybrids.

More emergence (8.75 plants $\mathrm{m}^{-2}$ ) was recorded for the field plowed at night and sown immediately, followed by (7.92 plants $\left.\mathrm{m}^{-2}\right)$ the same treatment sown 12 hours later. The lower number of plants $\left(5.50\right.$ plants $\left.\mathrm{m}^{-2}\right)$ was recorded for the field plowed at daytime and sown immediately. The interaction between plowing and sowing time and hybrids (PSxH) showed that generally emergence per unit area was more for all the hybrids when the field was plowed at night and sown immediately, followed by the same field sown 12 hours later. The lowest emergence per unit area was recorded for all hybrids when the field was plowed at usual daytime and sown immediately.
The detailed study of the ANOVA revealed that the significant difference among emergence per unit area was the result of plowing time while sowing time had no effect. The planned means comparison among plowing time showed that more number of plants $\left(8.33 \mathrm{~m}^{-2}\right)$ was recorded for the field plowed at night while lower number of plants $\left(5.71 \mathrm{~m}^{-2}\right)$ for the field plowed at usual daytime. The interaction of plowing and sowing time (PxS) affected emergence significantly which showed that the field when plowed at night and sown immediately produced more plants per unit area compared to daytime plowing and immediate sowing.

Emergence per unit area is considered an important agronomic and physiological parameter that determines the vegetative stand of crop. It is generally believed that good crop stand is a prerequisite for higher yield. The data revealed that plowing time had affected emergence per unit area significantly. The effect of different sowing times was not significant. More emergence $\mathrm{m}^{-2}$ was recorded when the field was plowed at night. Similarly, the lower number of 
plants $\mathrm{m}^{-2}$ was recorded for the field plowed at usual daytime. The interaction of plowing and sowing time affected emergence significantly which showed that the field plowed at night and sown immediately produced more plants $\mathrm{m}^{-2}$ compared to daytime plowing and immediate sowing. It might be due the reason that maize seeds are relatively larger and in order to complete germination needs sufficient moisture for imbibition. Field preparation in night might favors to conserve moisture and ensure sufficient moisture to the crop to complete the process of germination. This resulted optimum seedling emergence and ensured optimum plant stand and hence reflected greater production. Summer in Khyber
Pakhtunkhwa is relatively hot and creates considerable loss of soil moisture if fields are plowed at normal daytime. Furthermore, the temperature at sowing time has a vital role in germination. Very low or high temperature significantly affects the germination. Sowing in dark probably provided proper temperature for the activation of enzyme responsible for germination, resulting in greater emergence per unit land area. [7] reported that emergence is the result of imbibition and enzyme activation. [6] reported that a proper range of temperature is crucial for germination, above or below which germination is affected.

Table 2. Effect of plowing and sowing time on emergence $\mathrm{m}^{-2}$ of various maize hybrids

\begin{tabular}{|c|c|c|c|c|c|}
\hline \multirow{2}{*}{$\begin{array}{c}\text { Plowing } \\
\text { time }\end{array}$} & Sowing & \multicolumn{3}{|c|}{ Hybrids } & \multirow{2}{*}{ Mean } \\
\cline { 3 - 5 } & Time & $\mathrm{H} 1$ & $\mathrm{H} 2$ & $\mathrm{H} 3$ & \\
\hline \multirow{2}{*}{ Night } & Immediate & 9.50 & 8.50 & 8.25 & $8.75 \mathrm{a}$ \\
\cline { 2 - 5 } & 12 hrs later & 8.75 & 7.50 & 7.50 & $7.92 \mathrm{a}$ \\
\hline \multirow{2}{*}{ Day } & Immediate & 5.50 & 5.75 & 5.25 & $5.50 \mathrm{~b}$ \\
\cline { 2 - 5 } & 12 hrs later & 6.25 & 6.00 & 5.50 & $5.92 \mathrm{~b}$ \\
\hline & Mean & 7.50 & 6.94 & 6.63 & \\
\hline
\end{tabular}

LSD (0.05) for time $=0.85$, LSD (0.05) for hybrids $=$ NS, LSD (0.05) for interaction $=0.91$

H1 = Monsanto-2021, H2 = Rafhan-3313, H3 = Rafhan-3304

Mean values of various categories followed by different letters are statistically different at $5 \%$ level of probability

Planned means comparison with statistical significance

\begin{tabular}{|l|c|c|c|c|}
\hline \multicolumn{1}{|c|}{ Contrasts } & \multicolumn{3}{|c|}{${\text { Emergence } \mathbf{~ m}^{-2}}_{\text {Significance }}$} \\
\hline Night vs. day (plowing) & 8.33 & vs. & 5.71 & $* *$ \\
\hline Immediate vs. late (sowing) & 7.13 & vs. & 6.92 & NS \\
\hline Interaction (P x S) & - & - & - & $* *$ \\
\hline
\end{tabular}

$* *$ = Significant at $1 \%$ level of probability

NS = Non-significant

\section{Days to $50 \%$ tasseling}

Data collected on days to $50 \%$ tasseling of different maize hybrids as affected by plowing and sowing time is summarized in Table 3. Statistical analysis of the data revealed that plowing and sowing time (PS) had significant effect on days to $50 \%$ tasseling. There was no significant difference in days 50\% tasseling among the hybrids $(\mathrm{H})$ and their interaction with plowing and sowing time ( $\mathrm{PSxH})$.

The field plowed at night and sown immediately took more days (53.2) to develop $50 \%$ tassels, followed by $(52.7$ days) the same treatment sown 12 hours later. Early development of $50 \%$ tassels (52.4 days) was recorded for the field 
plowed at usual daytime and sown immediately.

Further splitting of the ANOVA confirmed that plowing time had significantly affected days to $50 \%$ tasseling. Sowing time and their interaction with plowing time $(\mathrm{PxS})$ showed no significant effect on days to tasseling. The planned means comparison showed that plowing the field at night delayed (52.9days) tasseling while early tasseling (52.5 days) was recorded when the field was plowed at daytime.

Days to $50 \%$ tasseling and silking are considered as the termination of vegetative stage and start of reproductive cycle in maize. The data illustrated that plowing time had significantly affected days to $50 \%$ tasseling, 50\% silking and maturity. There was no contribution of sowing time for these observations. The field plowed at night took more days to tasseling, silking and maturity. Early tasseling, silking and maturity were recorded for the field plowed at usual daytime. Such responses could be due to quicker emergence (Table 1) and more number of plants per unit area (Table 2). Weeds free fields seem to be the most important contribution to prolong the vegetative cycle, resulting in delayed tasseling, silking and maturity. These results are in accordance [8] who reported that number of days to tasseling, silking and maturity was increased in weed free plots as compared to control plot which was not weeded throughout the growing period of maize.

Table 3. Effect of plowing and sowing time on days to $50 \%$ tasseling of various maize hybrids

\begin{tabular}{|c|c|c|c|c|c|}
\hline \multirow{2}{*}{$\begin{array}{l}\text { Plowing } \\
\text { time }\end{array}$} & \multirow{2}{*}{$\begin{array}{c}\text { Sowing } \\
\text { Time }\end{array}$} & \multicolumn{3}{|c|}{ Hybrids } & \multirow{2}{*}{ Mean } \\
\hline & & $\mathrm{H} 1$ & $\mathrm{H} 2$ & H3 & \\
\hline \multirow{2}{*}{ Night } & Immediate & 53.8 & 53.3 & 52.5 & $53.2 \mathrm{a}$ \\
\hline & $12 \mathrm{hrs}$ later & 53.3 & 52.3 & 52.5 & $52.7 \mathrm{ab}$ \\
\hline \multirow{3}{*}{ Day } & Immediate & 52.5 & 52.5 & 52.3 & $52.4 \mathrm{ab}$ \\
\hline & 12 hrs later & 52.5 & 52.5 & 52.5 & $52.5 \mathrm{~b}$ \\
\hline & Mean & 53.0 & 52.6 & 52.4 & \\
\hline
\end{tabular}

LSD $(0.05)$ for time $=0.71, \operatorname{LSD}(0.05)$ for hybrids $=\mathrm{NS}, \mathrm{LSD}(0.05)$ for interaction $=\mathrm{NS}$

H1 = Monsanto-2021, H2 = Rafhan-3313, H3 = Rafhan-3304

Mean values of various categories followed by different letters are statistically different at $5 \%$ level of probability.

Planned means comparison with statistical significance

\begin{tabular}{|l|c|c|c|c|}
\hline \multicolumn{1}{|c|}{ Contrasts } & \multicolumn{3}{c|}{ Days to 50 \% tasseling } & Significance \\
\hline Night vs. day (plowing) & 52.9 & vs. & 52.5 & $*$ \\
\hline Immediate vs. late (sowing) & 52.8 & vs. & 52.6 & NS \\
\hline Interaction ( P x S ) & - & - & - & NS \\
\hline
\end{tabular}

NS = Non-significant

$*$ Significant at $5 \%$ level of probability

\section{Days to $50 \%$ silking}

Data on days to $50 \%$ silking of different maize hybrids as affected by plowing and sowing time is provided in Table 4. Analysis of the data showed that plowing and sowing time (PS) showed significant effect on days to $50 \%$ silking. There were no significant differences in days to $50 \%$ silking among the hybrids. There was also no interaction between plowing and sowing time and hybrids for days to $50 \%$ silking.

The delayed silking (58.8 days) was observed when the field was plowed at night and sown immediately, followed by the 
same treatment sown 12 hours later which took 58.4 days to $50 \%$ silking. Early development of silks (57.6 days) was seen in the field plowed at usual daytime and sown immediately. The splitting of the ANOVA provided detailed information about the effect of plowing and sowing time. The field plowed at night took more days to develop silks than the field plowed at usual daytime. Sowing time and their interaction with plowing (PxS) had also no effect on days to $50 \%$ silking. It was known from the planned means comparison that delayed silking (58.6 days) was recorded for the field plowed at night while early silking (57.7 days) for the field plowed at usual daytime.

Days to $50 \%$ tasseling and silking are considered as the termination of vegetative stage and start of reproductive cycle in maize. The data illustrated that plowing time had significantly affected days to $50 \%$ tasseling, 50\% silking and maturity. There was no contribution of sowing time for these observations. The field plowed at night took more days to tasseling, silking and maturity. Early tasseling, silking and maturity were recorded for the field plowed at usual daytime. Such responses could be due to quicker emergence (Table 1) and more number of plants per unit area (Table 2). Weeds free fields seem to be the most important contribution to prolong the vegetative cycle, resulting in delayed tasseling, silking and maturity. These results are in accordance with [9] who reported that number of days to tasseling, silking and maturity was increased in weed free plots as compared to control plot which was not weeded throughout the growing period of maize.

Table 4. Effect of plowing and sowing time on days to $50 \%$ silking of various maize hybrids

\begin{tabular}{|c|c|c|c|c|c|}
\hline \multirow{2}{*}{$\begin{array}{c}\text { Plowing } \\
\text { time }\end{array}$} & \multirow{2}{*}{$\begin{array}{l}\text { Sowing } \\
\text { time }\end{array}$} & \multicolumn{3}{|c|}{ Hybrids } & \multirow{2}{*}{ Mean } \\
\hline & & H1 & $\mathrm{H} 2$ & H3 & \\
\hline \multirow{2}{*}{ Night } & Immediate & 59.3 & 58.8 & 58.3 & $58.8 \mathrm{a}$ \\
\hline & 12 hrs later & 58.8 & 58.3 & 58.3 & $58.4 \mathrm{ab}$ \\
\hline \multirow{3}{*}{ Day } & Immediate & 57.8 & 58.3 & 56.8 & $57.6 \mathrm{ab}$ \\
\hline & 12 hrs later & 57.5 & 57.8 & 58.3 & $57.8 \mathrm{~b}$ \\
\hline & Mean & 58.3 & 58.3 & 57.9 & \\
\hline
\end{tabular}

LSD (0.05) for time $=1.04, \operatorname{LSD}(0.05)$ for hybrids $=\mathrm{NS}, \mathrm{LSD}(0.05)$ for interaction $=\mathrm{NS}$

$\mathrm{H} 1=$ Monsanto-2021, H2 = Rafhan-3313, H3 = Rafhan-3304

Mean values of various categories followed by different letters are statistically different at $5 \%$ level of probability.

Planned means comparison with statistical significance

\begin{tabular}{|l|l|l|l|l|}
\hline \multicolumn{1}{|c|}{ Contrasts } & \multicolumn{3}{c|}{ Days to 50 \% silking } & \multicolumn{1}{c|}{ Significance } \\
\hline Night vs. day (plowing) & 58.6 & vs. & 57.7 & $* *$ \\
\hline Immediate vs. late (sowing) & 58.2 & vs. & 58.1 & NS \\
\hline Interaction ( P x S ) & - & - & - & NS \\
\hline
\end{tabular}

NS = Non-significant

$* *=$ Significant at $1 \%$ level of probability

Leaf area of the cob bearing node $\left(\mathrm{cm}^{2}\right)$

Data obtained on leaf area near maturity of various maize hybrids as affected by plowing and sowing time is offered in Table 5. Analysis of variance of the data showed that plowing and sowing time (PS) had significantly affected leaf area. The analysis also showed that various hybrids have significantly different leaf area. The interaction of plowing and sowing time and 
hybrids (PSxH) also showed significantly different results for leaf area.

Larger leaf area $\left(856 \mathrm{~cm}^{2}\right)$ was recorded for the treatment sown immediately after plowing at night, followed by $\left(844 \mathrm{~cm}^{2}\right)$ the same field sown 12 hours later. Smaller leaf area $\left(814 \mathrm{~cm}^{2}\right)$ was recorded for the field plowed at usual daytime and sown immediately. Larger leaf area was recorded for $\mathrm{H} 1 \quad\left(849 \mathrm{~cm}^{2}\right)$, followed by $\mathrm{H} 2$ (833 $\left.\mathrm{cm}^{2}\right)$. Smaller leaf area was recorded for $\mathrm{H} 3$ $\left(824 \mathrm{~cm}^{2}\right)$. The interaction between plowing and sowing time and hybrids (PSxH) showed that usually leaf area was larger for all the hybrids sown immediately after plowing the field at night, followed by the same field sown 12 hours later. The smaller leaf area was recorded for all hybrids when the field was plowed at usual daytime and sown immediately.

The ANOVA showed that plowing time and the interaction of plowing and sowing time (PxS) had significantly affected leaf area. The interaction of plowing and sowing time revealed that sowing the field immediately after plowing at night gave better results in term of leaf area compared to sowing immediately after plowing at usual daytime. It was observed from the planned means comparison that larger leaf area $\left(850 \mathrm{~cm}^{2}\right)$ was recorded for the field plowed at night and smaller $\left(821 \mathrm{~cm}^{2}\right)$ for the field plowed at usual daytime.
Leaf area is considered important for capturing sun light. Leaves are photosynthetic machinery of the plants. The data indicated that plowing time significantly affected leaf area. Larger leaf area was recorded for the field plowed at night. Smaller leaf area was recorded for the field plowed at usual daytime. The interaction of plowing and sowing time revealed that sowing immediately after plowing the field at night gave better results in term of leaf area compared to sowing immediately after plowing at usual daytime. Such outcome could be the result of optimum moisture at the time of germination which resulted strong seedlings and good emergence. The plots which produced larger leaf area might have ensured optimum availability of nutrients because of fewer weeds in those plots. [10] reported that total shoot yield of maize was reduced significantly when weeds were present after the crop had developed 7-8 leaves. [11] studied that weed competition up to 20 days from sowing significantly reduced the number of maize leaves per plant. Generally high yielding varieties have broad leaves. Such results are in accordance with [12] who concluded that high yielding varieties tended to be upright with broad leaves than low yielding cultivars.

Table 5. Effect of plowing and sowing time on leaf area $\left(\mathrm{cm}^{2}\right)$ of the cob bearing node near maturity of various maize hybrids

\begin{tabular}{|c|c|c|c|c|c|}
\hline \multirow{2}{*}{$\begin{array}{c}\text { Plowing } \\
\text { time }\end{array}$} & $\begin{array}{c}\text { Sowing } \\
\text { Time }\end{array}$ & $\mathrm{H} 1$ & $\mathrm{H} 2$ & $\mathrm{H} 3$ & \multirow{2}{*}{ Mean } \\
\cline { 3 - 6 } \multirow{2}{*}{ Night } & Immediate & 872 & 854 & 842 & $856 \mathrm{a}$ \\
\cline { 2 - 6 } & 12 hrs later & 858 & 839 & 834 & $844 \mathrm{~b}$ \\
\hline \multirow{2}{*}{ Day } & Immediate & 828 & 813 & 802 & $814 \mathrm{~d}$ \\
\cline { 2 - 6 } & 12 hrs later & 837 & 828 & 819 & $828 \mathrm{c}$ \\
\hline & Mean & $849 \mathrm{a}$ & $833 \mathrm{~b}$ & $824 \mathrm{c}$ & \\
\hline
\end{tabular}

LSD (0.05) for time $=1.72$, LSD $(0.05)$ for hybrids $=1.35$, LSD $(0.05)$ for interaction $=1.54$

H1 = Monsanto-2021, H2 = Rafhan-3313, H3 = Rafhan-3304

Mean values of various categories followed by different letters are statistically different at $5 \%$ level of probability. 
Planned means comparison with statistical significance

\begin{tabular}{|l|c|c|c|c|}
\hline \multicolumn{1}{|c|}{ Contrasts } & \multicolumn{3}{|c|}{ Leaf area $\left(\mathbf{c m}^{\mathbf{2}}\right)$} & Significance \\
\hline Night vs. day (plowing) & 850 & vs. & 821 & $* *$ \\
\hline Immediate vs. late (sowing) & 835 & vs. & 836 & NS \\
\hline Interaction ( P x S ) & - & - & - & $* *$ \\
\hline
\end{tabular}

$* *=$ Significant at $1 \%$ level of probability, NS = Non-significant

\section{Plant height (cm)}

Data related to plant height of various maize hybrids as affected by plowing and sowing time is given in Table 6 . Analysis of the data showed that plowing and sowing time (PS) and their interaction with hybrids (PSxH) had significantly affected plant height. There were also significant differences in height of various hybrids.

Taller $(273 \mathrm{~cm})$ plants were observed when the field was plowed at night and sown immediately, followed by $(269 \mathrm{~cm})$ the same field sown 12 hours later. Shorter $(259 \mathrm{~cm})$ plants among different treatments were recorded for the field plowed at usual daytime and sown immediately. More height $(271 \mathrm{~cm})$ was recorded for $\mathrm{H} 1$, followed by $\mathrm{H} 2(266 \mathrm{~cm})$ and $\mathrm{H} 3(261 \mathrm{~cm})$. The interaction between (PSxH) indicated that in general all hybrids were taller when sown immediately after plowing at night, followed by the same treatment sown 12 hours later. The shorter plants were recorded for the field plowed at daytime and sown immediately.

The ANOVA Table indicates that plowing time and the interaction of plowing and sowing time $(\mathrm{PxS})$ showed significant while sowing time showed no significant effect on plant height. The field plowed at night and sown immediately produced taller plants than the field plowed at daytime and sown immediately. Planned means comparison showed that taller plants $(271 \mathrm{~cm})$ were recorded for the field plowed at night and shorter $(262 \mathrm{~cm})$ for the field plowed at daytime.

Plant height is a function of genetic as well as the environmental conditions. It is considered as the expression of its full vegetative potential. The data confirmed that plant height was significantly affected by plowing time. Taller plants were observed when the field was plowed at night. Shorter plants were recorded for the field plowed at usual daytime. The interaction of plowing and sowing time had significantly affected plant height. The field plowed at night and sown immediately produced taller plants than the field plowed at daytime and sown immediately. The reason might be healthy plants at the beginning due proper moisture and optimum temperature. The other reason could be less weeds infestation which encouraged the plants to gain height. Similar results were obtained by [8].

Table 6. Effect of plowing and sowing time on plant height $(\mathrm{cm})$ of various maize hybrids

\begin{tabular}{|c|c|c|c|c|c|}
\hline \multirow{2}{*}{$\begin{array}{l}\text { Plowing } \\
\text { time }\end{array}$} & \multirow{2}{*}{$\begin{array}{c}\text { Sowing } \\
\text { Time }\end{array}$} & \multicolumn{3}{|c|}{ Hybrids } & \multirow{2}{*}{ Mean } \\
\hline & & $\mathrm{H} 1$ & $\mathrm{H} 2$ & $\mathrm{H} 3$ & \\
\hline \multirow{2}{*}{ Night } & Immediate & 280 & 272 & 267 & $273 \mathrm{a}$ \\
\hline & 12 hrs later & 274 & 268 & 264 & $269 \mathrm{~b}$ \\
\hline \multirow{3}{*}{ Day } & Immediate & 264 & 259 & 254 & $259 \mathrm{~d}$ \\
\hline & 12 hrs later & 268 & 264 & 261 & $264 c$ \\
\hline & Mean & $271 \mathrm{a}$ & $266 \mathrm{~b}$ & $261 \mathrm{c}$ & \\
\hline
\end{tabular}

$\operatorname{LSD}(0.05)$ for time $=1.49, \operatorname{LSD}(0.05)$ for hybrids $=1.13, \operatorname{LSD}(0.05)$ for interaction $=1.28$

H1 = Monsanto-2021, H2 = Rafhan-3313, H3 = Rafhan-3304

Mean values of various categories followed by different letters are statistically different at $5 \%$ level of probability. 
Planned means comparison with statistical significance

\begin{tabular}{|l|c|c|c|c|}
\hline \multicolumn{1}{|c|}{ Contrasts } & \multicolumn{3}{|c|}{ Plant height (cm) } & Significance \\
\hline Night vs. day (plowing) & 271 & vs. & 262 & $* *$ \\
\hline Immediate vs. late (sowing) & 266 & vs. & 267 & NS \\
\hline Interaction ( P x S ) & - & - & - & $* *$ \\
\hline
\end{tabular}

$* *=$ Significant at $1 \%$ level of probability, NS = Non-significant

\section{Days to maturity}

Data on days to maturity as affected by plowing and sowing time is provided in Table 7. Analysis of the data showed that plowing and sowing time (PS) and their interaction with hybrids (PSxH) had significantly affected days to maturity. Days to maturity were also significantly different among various hybrids.

The field plowed at night and sown immediately delayed the maturity (115 days), followed by (113 days) the same field sown 12 hours later. The earlier maturity (110 days) was observed for the field plowed at usual daytime and sown immediately. More days (114) to maturity were recorded for $\mathrm{H} 1$, followed by $\mathrm{H} 2$ (112 days) and $\mathrm{H} 3$ (111 days). The interaction of plowing and sowing time and hybrids $(\mathrm{PSxH})$ indicated that all hybrids matured late when sown immediately after plowing at night, followed by the same field sown 12 hours later. Similarly, all hybrids matured earlier when sown immediately after plowing the field at usual daytime.

The detailed interpretation of the ANOVA clarified that the significant differences in days to maturity were due to plowing time while sowing time had no effect on maturity. The ANOVA also revealed that the interaction between plowing and sowing time (PxS) had significantly affected days to maturity. Delayed maturity was recorded in those treatments which were plowed at night and sown immediately compared to those which were plowed at daytime and sown immediately. Observations obtained from the comparison of planned means showed that late maturity (114 days) were recorded for the field plowed at night and early maturity (111 days) for the field plowed at daytime.

Table 7. Effect of plowing and sowing time on days to maturity of various maize hybrids

\begin{tabular}{|c|c|c|c|c|c|}
\hline \multirow{2}{*}{$\begin{array}{c}\text { Plowing } \\
\text { time }\end{array}$} & \multirow{2}{*}{$\begin{array}{c}\text { Sowing } \\
\text { Time }\end{array}$} & \multicolumn{3}{|c|}{ Hybrids } & \multirow{2}{*}{ Mean } \\
\hline & & H1 & $\mathrm{H} 2$ & H3 & \\
\hline \multirow{2}{*}{ Night } & Immediate & 117 & 115 & 114 & $115 \mathrm{a}$ \\
\hline & 12 hrs later & 114 & 113 & 112 & $113 \mathrm{~b}$ \\
\hline \multirow{3}{*}{ Day } & Immediate & 111 & 110 & 108 & $110 \mathrm{~d}$ \\
\hline & 12 hrs later & 113 & 112 & 111 & $112 \mathrm{c}$ \\
\hline & Mean & $114 \mathrm{a}$ & $112 \mathrm{~b}$ & $111 \mathrm{c}$ & \\
\hline
\end{tabular}

LSD (0.05) for time $=0.79$, LSD (0.05) for hybrids $=0.72, \operatorname{LSD}(0.05)$ for interaction $=0.82$

H1 = Monsanto-2021, H2 = Rafhan-3313, H3 = Rafhan-3304,

Mean values of various categories followed by different letters are statistically different at $5 \%$ level of probability. 
Planned means comparison with statistical significance

\begin{tabular}{|l|c|c|c|c|}
\hline \multicolumn{1}{|c|}{ Contrasts } & \multicolumn{3}{|c|}{ Days to maturity } & Significance \\
\hline Night vs. day (plowing) & 114 & vs. & 111 & $* *$ \\
\hline Immediate vs. late (sowing) & 112 & vs. & 112 & NS \\
\hline Interaction ( P x S ) & - & - & - & $* *$ \\
\hline
\end{tabular}

NS = Non-significant,

$* *=$ Significant at $1 \%$ level of probability

Stover yield $\left(\mathrm{kg} \mathrm{ha}^{-1}\right)$

Data obtained on stover yield of various maize hybrids as affected by plowing and sowing time is summed up in Table 8 . Analysis of variance of the data verified that plowing and sowing time (PS) had significantly affected stover yield. The analysis also validated that the interaction of plowing and sowing time and hybrids (PSxH) was significantly different regarding stover yield. The variations in stover yield amongst various hybrids were also significantly different.

Highest (12544 kg ha-1) stover yield was recorded for the field plowed at night and sown immediately, followed by $(12111 \mathrm{~kg}$ $\mathrm{ha}^{-1}$ ) the same field sown 12 hours later. Lowest (11321 kg ha ${ }^{-1}$ ) stover yield was recorded for the treatment plowed at usual daytime and sown immediately. The data also proved that more $\left(12670 \mathrm{~kg} \mathrm{ha}^{-1}\right)$ stover yield was recorded for $\mathrm{H} 1$. The interaction of plowing and sowing time and hybrids (PSxH) indicated that highest stover yield was obtained by all hybrids when sown immediately after plowing at night, followed by the same treatment sown 12 hours later.
All hybrids attained least stover yield when sown immediately after plowing at usual daytime.

The ANOVA table shows that differences in stover yield were the consequence of plowing time. Sowing time had no impact. The interaction of plowing and sowing time (PxS) resulted significant variation in stover yield. Results of the planned means comparison demonstrated that more (12328 $\mathrm{kg} \mathrm{ha}^{-1}$ ) stover yield was recorded for the field plowed at night while least $(11484 \mathrm{~kg}$ $\mathrm{ha}^{-1}$ ) for the field plowed at usual daytime.

Stovers are used as fodder which is an additional advantage of growing maize. Stover yield was significantly affected by plowing time. Highest stover yield was recorded for the field plowed at night. Lowest stover yield was recorded for the treatment plowed at usual daytime. The interaction of plowing and sowing time resulted significant variation in stover yield. The main reason of higher stover yield could be lower weeds infestation. [9] reported that stover yield was increased $8.7 \%$ in the plots weeded 30 days after emergence as compared to the control plot.

Table 8. Effect of plowing and sowing time on stover yield $\left(\mathrm{kg} \mathrm{ha}^{-1}\right)$ of various maize hybrids

\begin{tabular}{|c|c|c|c|c|c|}
\hline $\begin{array}{c}\text { Plowing } \\
\text { time }\end{array}$ & \multirow{2}{*}{$\begin{array}{c}\text { Sowing } \\
\text { Time }\end{array}$} & \multicolumn{3}{|c|}{ Hybrids } & \multirow{2}{*}{ Mean } \\
\cline { 3 - 6 } Night & Immediate & 13263 & H2 & H3 & \\
\cline { 2 - 6 } & $12 \mathrm{hrs}$ later & 12998 & 11896 & 11842 & $12544 \mathrm{a}$ \\
\hline \multirow{2}{*}{ Day } & Immediate & 12241 & 11138 & 10585 & $12111 \mathrm{~b}$ \\
\cline { 2 - 6 } & $12 \mathrm{hrs}$ later & 12177 & 11619 & 11144 & $11647 \mathrm{c}$ \\
\hline & Mean & $12670 \mathrm{a}$ & $11795 \mathrm{~b}$ & $11252 \mathrm{c}$ & \\
\hline
\end{tabular}

$\operatorname{LSD}(0.05)$ for time $=170.19, \operatorname{LSD}(0.05)$ for hybrids $=231.70, \operatorname{LSD}(0.05)$ for interaction $=263.53$

H1 = Monsanto-2021, H2 = Rafhan-3313, H3 = Rafhan-3304

Mean values of various categories followed by different letters are statistically different at $5 \%$ level of probability 
Planned means comparison with statistical significance

\begin{tabular}{|l|c|c|c|c|}
\hline \multicolumn{1}{|c|}{ Contrasts } & \multicolumn{2}{c|}{ Stover yield (kg ha ${ }^{-1}$ ) } & Significance \\
\hline Night vs. day (plowing) & 12328 & vs. & 11484 & $* *$ \\
\hline Immediate vs. late (sowing) & 11933 & vs. & 11879 & NS \\
\hline Interaction ( P x S ) & - & - & - & $* *$ \\
\hline
\end{tabular}

NS $=$ Non-significant, $* *=$ Significant at $1 \%$ level of probability

\section{Crop growth rate $\left(\mathrm{gm}^{-2} \cdot \mathrm{day}^{-1}\right)$}

Data on crop growth rate (CGR) of various maize hybrids as affected by plowing and sowing time is obtainable in Table 9. Analysis of variance of the data indicated that plowing and sowing time (PS) as well as the interaction amongst plowing and sowing time and hybrids (PSxH) had significantly affected CGR. The hybrids had also significantly different crop growth rate.

The field plowed at night and sown immediately accelerated $\left(25.18 \mathrm{gm}^{-2} \mathrm{day}^{-1}\right)$ the CGR, followed by $\left(24.78 \mathrm{gm}^{-2}\right.$. day $\left.{ }^{-1}\right)$ the same treatment sown 12 hours later. Plowing the field at usual daytime and sowing immediately slowed down (23.88 g $\mathrm{m}^{-2} \mathrm{day}^{-1}$ ) the CGR. Various hybrids had significantly different CGR. Faster CGR (25.56 $\mathrm{gm}^{-2}$. day $\left.{ }^{-1}\right)$ was recorded for $\mathrm{H} 1$, followed by $\mathrm{H} 2$ (24 $\mathrm{gm}^{-2}$. day $\left.{ }^{-1}\right)$ and $\mathrm{H} 3$ (23.70 $\left.\mathrm{gm}^{-2} \cdot \mathrm{day}^{-1}\right)$. The interaction of $(\mathrm{PSxH})$ revealed that faster CGR was observed, for all hybrids, when sown immediately after plowing at night. The slowest CGR was recorded for all hybrids when the field was plowed at daytime and sown immediately. The detailed study of the
ANOVA indicated that the faster CGR was the outcome of plowing time while sowing time had no effect. The interaction of plowing and sowing time resulted significant variation in CGR. Planned means comparison showed that faster CGR (24.98 $\mathrm{gm}^{-2}$. $\mathrm{day}^{-1}$ ) was recorded for the field plowed at night. The slowest CGR (24.12 $\mathrm{gm}^{-2} \cdot \mathrm{day}^{-1}$ ) was recorded for the field plowed at usual daytime.

CGR is the function of genetic makeup of a crop as well as environmental conditions. The data revealed that plowing the field at night accelerated the crop growth rate. The interaction of plowing and sowing time resulted significant variation in CGR. Sufficient availability of growth factors ensured maximum crop growth rate. CGR was higher because moisture and nutrients were optimum for crop growth. Weeds infestation was also less in the plots plowed at night and availability of all the contributing factors was sufficient. [13] found that weed cover in intensively cultivated land in North Bavaria (Germany) could be reduced from $80-2 \%$ if cultivation was carried out during darkness.

Table 9. Effect of plowing and sowing time on crop growth rate $\left(\mathrm{gm}^{-2} \cdot \mathrm{day}^{-1}\right)$ of various maize hybrids

\begin{tabular}{|c|c|c|c|c|c|}
\hline \multirow{2}{*}{$\begin{array}{l}\text { Plowing } \\
\text { time }\end{array}$} & \multirow{2}{*}{$\begin{array}{l}\text { Sowing } \\
\text { Time }\end{array}$} & \multicolumn{3}{|c|}{ Hybrids } & \multirow{2}{*}{ Mean } \\
\hline & & H1 & $\mathrm{H} 2$ & H3 & \\
\hline \multirow{2}{*}{ Night } & Immediate & 26.37 & 24.98 & 24.17 & $25.18 \mathrm{a}$ \\
\hline & $12 \mathrm{hrs}$ later & 25.91 & 24.64 & 23.79 & $24.78 \mathrm{~b}$ \\
\hline \multirow{3}{*}{ Day } & Immediate & 24.80 & 23.75 & 23.07 & $23.88 \mathrm{~d}$ \\
\hline & 12 hrs later & 25.16 & 24.17 & 23.77 & $24.37 \mathrm{c}$ \\
\hline & Mean & $25.56 \mathrm{a}$ & $24.39 \mathrm{~b}$ & $23.70 \mathrm{c}$ & \\
\hline
\end{tabular}

$\operatorname{LSD}(0.05)$ for time $=0.1078, \operatorname{LSD}(0.05)$ for hybrids $=0.1140, \operatorname{LSD}(0.05)$ for interaction $=0.1297$

H1 = Monsanto-2021, H2 = Rafhan-3313, H3 = Rafhan-3304

Mean values of various categories followed by different letters are statistically different at $5 \%$ level of probability. 
Planned means comparison with statistical significance

\begin{tabular}{|l|c|c|c|c|}
\hline \multicolumn{1}{|c|}{ Contrasts } & \multicolumn{3}{|c|}{ Crop growth rate $\left(\mathbf{g m}^{-\mathbf{2}}\right.$.day $\left.\mathbf{1}\right)$} & Significance \\
\hline Night vs. day (plowing) & 24.98 & vs. & 24.12 & $* *$ \\
\hline Immediate vs. late (sowing) & 24.53 & vs. & 24.57 & NS \\
\hline Interaction ( P x S ) & - & - & - & $* *$ \\
\hline
\end{tabular}

NS $=$ Non-significant, $* *=$ Significant at $1 \%$ level of probability

\section{Conclusion and recommendations}

In the light of results obtained on various observations, the following conclusion can be made. Plowing time had significantly influenced all observed parameters while sowing time showed no impact. Plowing the field at night showed best results in term of crop growth rate as compared to the field plowed at usual day time. Maize hybrid i.e. Monsanto-2021 gave better results as compared to other hybrids used in the experiment. On the basis of results obtained from this study, it is strongly suggested that final plowing should be done at night for best results. Sowing can be done either immediately after plowing or on the subsequent day of plowing. Hybrids should be used to get high production of Maize

\section{Authors' contributions}

Conceived and designed the experiments: A Khan, Performed the experiments: A Khan \& F Gul, Analyzed the data: A Khan, Y Jamal \& H Ullah, Contributed materials: A Khan, I Naeem \& MA Khan, Wrote the paper: A Khan \& J Ali.

\section{Acknowledgement}

The authors are thankful to the Agricultural Research Station Buner for conducting this experiment on their resources.

\section{References}

1. Shah STH, Zamir ISM, Waseem M, Ali A, Tahir M \& Khalid BW (2009).Growth and yield response of Maize (zea mays) to organic and inorganic sources of nitrogen. Pakistan journal of life and social sciences 7(2): 108-111

2. Ohdi S, Mashadi HR, Ashrafi TR \&
Mesgaran MBP (2010). Modelling the effect of light intensity and duration of exposure on seed germination of phalaris minor and poa annua Weed Research 50: 209-217

3. Din US, Ramzan M, Khan R, Rahman UM, Haroon M, Khan AT \& Samad A (2013). Impact of tillage and mulching practices on weed biomass and yield components on maize under rainfed condition. Pakistan journal of weed science and research 19(2): 201208,2013

4. Gardner FP, Pearce RB and Mitchell RL (1985). Physiology of crop plants. $1^{\text {st }}$ Edition. Iowa State University Press, Ames, USA. pp 327.

5. Liebman RGD \& Torrie JH (1997). Analysis of covariance, In: Principles and procedures of statistics: a biometrical Approach, McGraw-Hill, New York. pp. 401-437

6. Gallagher SR, Gringer KL, Synder MA, Pittman D \& Fuerst P (2013). Implications of Environmental Stress during Seed Development on Reproductive and Seed Bank Persistence Traits in Wild Oat (Avena fatua L.). Agronomy 3: 537-549

7. Logan DC, Miller HA, Sweet LJ \& Levear C (2001). Mitocondrial Biogenes during germination in Maize Embryos. Plant Physiol Feb 125(2): 662-672

8. Nawab K, Hatam M, Khan BA, Rasul K \& Mansoor M (1999). Study of some morphological characteristics in maize as affected by of time of weeding and 
plant spacing. Sarhad Journal of Agriculture 15(1): 21-24.

9. Nawab K, Hatam M, Wadan HD \& Khalil IH (1997). Effect of time of weeding and plant spacing on growth and grain yield of maize. Sarhad Journal of Agriculture 13(1): 55-60.

10. Liebman M, Bastiaans \& Buaman DT (2003). Weed Management in low external input and organic farming systems. Weed Biology and Management pp. 285-315.

11. Silva PSL, Silva PIB, Silva KMB, Oliviera VR \& Pontes F (2011). Corn growth and yield in competition with weeds. Planta Daninha (29) Dec (2011) 12. Lodhi MY, Marghazani IB, Hamayun K \& Marri MJ (2009). Comparative Performance study of Different oat Varietes Under Agro Climate of Sibi. The Journal of Animal \& Plant Sciences 19(1): 34-36

13. Cloutler DC, Wede RY, Preuzzl A \& Leblence ML (2007). Mechanical Weed Management. Non Chemical Weed Management (7): 109-117. 